\title{
Sequence of Stress-Induced Alterations in Indices of Synaptic and Transcriptional Activation in Parvocellular Neurosecretory Neurons
}

\author{
K. J. Kovács ${ }^{1,2}$ and P. E. Sawchenko' \\ 1 Laboratory of Neuronal Structure and Function, The Salk Institute for Biological Studies and Foundation for Medical \\ Research, La Jolla, California 92037, and 2/nstitute of Experimental Medicine, Budapest, Hungary
}

Immediate-early genes (IEGs) are widely used to mark endocrine hypothalamic neurons that are activated in response to stress, yet their relationship to the transcriptional control of relevant effector molecule expression is unclear. Acute ether stress provokes increased adrenocorticotropic hormone $(A C T H)$ and corticosterone secretion that peaks at 5 and 30 min, respectively, after the challenge. Using probes complementary to intronic sequences of genes encoding ACTH secretagogues in parvocellular neurosecretory neurons of the paraventricular nucleus, we found these events to be accompanied by rapid and transient increases in corticotropin-releasing factor heteronuclear RNA (CRF hnRNA; peak at $5 \mathrm{~min}$ ) and by a delayed upregulation of arginine vasopressin (AVP) hnRNA (120 min). To identify candidate mechanisms regulating peptide expression, we followed the timing of ether effects on representatives of three transcription factor classes: IEGs [c-fos and nerve growth factor I-B (NGFI-B)], a POU-domain factor (Brn-2), and the cAMP response element-binding protein (CREB), using antisera specific to its transcriptionally active, phosphorylated form (pCREB). After ether exposure, c-fos and NGFI-B mRNA induction were maximal at 30-60 min, whereas Fos protein peaked at 60-120 min. Brn-2 mRNA was expressed constitutively in the PVH and was unresponsive to stress. By contrast, pCREB was induced in parvocellular neurons with a time course parallel to that of CRF hnRNA expression. Stress-induced transcriptional activation of the CRF and AVP genes in hypophysiotropic neurons follows distinct time courses that are compatible with control mechanisms involving phosphorylation events and de novo protein synthesis, respectively.

Key words: arginine vasopressin; corticotropin-releasing factor; c-fos; cAMP; hypothalamo-pituitary-adrenal axis; neurosecretory neurons; stress
Parvocellular neurosecretory neurons that govern stress-induced adrenocorticotropic hormone (ACTH) secretion are localized discretely in the paraventricular hypothalamic nucleus (PVH) (Antoni, 1986). This cell cluster can express multiple bioactive peptides (Sawchenko et al., 1993b), several of which act as ACTH secretagogues. Foremost among these are corticotropin-releasing factor (CRF), which is required for pituitary-adrenal activation (Rivier et al., 1982) and imparts stimulatory tone on the axis, and arginine vasopressin (AVP), which potentiates CRF actions on corticotropes (Rivier et al., 1983), and is generally believed to be the most dominant of the cosecretagogues that determine situation-specific drive (Plotsky, 1991). Basal levels of AVP expression in hypophysiotropic neurons are low, but are upregulated in CRF-expressing cells by stress (Lightman and Young, 1988; DeGoeij et al., 1991; Sawchenko et al., 1993a; Herman, in press) or steroid withdrawal (Kiss et al., 1984; Sawchenko et al., 1984; Swanson and Simmons, 1989). Parvocellular neurons are not necessarily the only source of AVP in portal plasma (Antoni et al., 1990); nearby magnocellular neurosecretory elements may con-

\footnotetext{
Received July 17, 1995; revised Aug. 30, 1995; accepted Sept. 1, 1995
}

This work was supported by National Institutes of Health Grant NS-21182, Grant JF328 from the U.S.-Hungarian Science and Technology Joint Fund, and an International Research Scholars Program award from the Howard Hughes Medical Institute; it was conducted in part by the Foundation for Medical Research. We thank Drs. T. Curran, A. Ericsson, K. Mayo, J. Milbrandt, M. G. Rosenfeld, and T. G. Sherman for generously providing plasmids, Dr. M. Montminy for pCREB antisera and helpful discussions, Dr. J. P. Herman for sharing data in advance of publication, and Carlos Arias, Kris Trulock, and Belle Wamsley for expert technical, graphic/photographic, and editorial assistance, respectively.

Correspondence should be addressed to Dr. P. E. Sawchenko, The Salk Institute, P.O. Box 85800, San Diego, CA 92186.

Copyright $(\mathcal{C} 1995$ Society for Neuroscience $0270-6474 / 95 / 160262-12 \$ 05.00 / 0$ tribute through mechanisms that are incompletely understood (Holmes et al., 1986; Buma and Nieuwenhuys, 1987).

Much of the recent progress in identifying the individual hypothalamic effector neurons and extended circuitries that underlie adaptive responses to stress has come from the use of immediate-early genes (IEGs) as markers of neuronal activation. Despite the utility of induced IEG expression in providing generic indices of synaptic and/or transcriptional stimulation (Morgan and Curran, 1991), their relationship to the control of relevant effector molecule expression remains uncertain. It is critical, therefore, to distinguish between inferences drawn from IEG data as to targeting at the cellular versus molecular levels; the latter is complicated by the capacity of parvocellular neurosecretory neurons to express differentially multiple neuropeptides in a statedependent manner (Sawchenko et al., 1993b).

To identify possible molecular mechanisms regulating the two main CRFs in vivo, we compared the time course of stress-induced changes in the cxpression of the primary CRF and AVP transcripts with those of markers for representatives of three transcription factor classes. These included (1) the IEGs c-fos and nerve growth factor I-B (NGFI-B), which have been validated as markers of stress-related circuitry (Ceccatelli et al., 1989; Chan et al., 1993; Hoffman et al., 1993), but whose relationship to transcriptional control mechanisms is uncertain, (2) a member of the POU-domain family of tissue-specific developmental regulators, Brn-2, which is expressed in the PVH of adult animals (He et al., 1989), and (3) the transcriptionally active, phosphorylated form of the cAMP response element-binding protein (pCREB) (Gonzalez and Montminy, 1989). Functional binding sites for both Brn-2 and CREB have been identified on the CRF promoter (Seasholtz et 
al., 1988; Li et al., 1993). Exposure to ether vapor was chosen as a stress model, despite obvious difficulties in relating it to other paradigms and everyday life, because it is time-honored as a potent activator of ACTH and corticosterone secretion (e.g., Rivier et al., 1973), because these effects depend on afferent input to the PVH (e.g., Bruhn et al., 1984; Kovács and Makara, 1990), because the brevity of exposure required to activate the axis facilitates detection and interpretation of rapid cellular responses, and because pilot studies suggested that ether targets the parvocellular compartment of the PVH more discretely than other stress models we have examined.

This work has been presented in abstract form (Kovács and Sawchenko, 1994).

\section{MATERIALS AND METHODS}

Animals. Adult male Sprague-Dawley rats, weighing $225-275 \mathrm{gm}$, were used in all experiments. The animals were housed in a colony room under controlled temperature and humidity conditions, with lights on between 6:00 A.M. and 6:00 P.M., with food and water freely available. Experimental protocols were approved by the Institutional Animal Care and Use Committee of the Salk Institute.

Blood sampling and hormone assays. Hormone measures were carried out in a separate group of rats implanted $2 \mathrm{~d}$ earlier with jugular venous catheters under pentobarbital anesthesia. These were fashioned from PE-50 tubing with Silastic (Dow Corning, Corning, NY) tips that terminated near the atrium and were exteriorized in an interscapular position. On the day of testing, cannulae were opened, flushed with sterile heparin, and attached to a heparin-saline-filled extension tubing equipped with a swivel to allow the animals to move freely. The rats then remained undisturbed for 3.5-4 hr. Blood samples were collected immediately before and then at $5,15,30,60,120$, and $240 \mathrm{~min}$ after 5 min exposure to ether vapor. Blood was collected onto prechilled tubes containing $2 \mu \mathrm{l}$ of $20 \%$ EDTA, centrifuged, and plasma-stored at $-20^{\circ} \mathrm{C}$ until assay. Plasma ACTH was measured by direct radioimmunoassay (Kovács and Makara, 1988), using a rabbit antiserum (code 8514) that recognizes the midportion of human $\mathrm{ACTH}^{1-39}$. Intra- and interassay coefficients of variation were 4.7 and $7.0 \%$, respectively. Plasma corticosterone was measured without extraction, using an antiserum raised in rabbits against a corticosterone-carboxylmethyloxime-BSA conjugate and ${ }^{125}$ I-labeled corticosterone-carboxymethyloxime-tyrosine-methylester as a tracer. Interference by plasma transcortin was eliminated by treatment at low $\mathrm{pH}$. The sensitivity of the assay was $0.1 \mathrm{pmol} / \mathrm{tube}$; intra- and interassay coefficients of variation were 6.4 and $23.8 \%$, respectively.

Ether stress. Animals were housed singly and adapted to handling for 2 $\mathrm{d}$ before treatment to minimize nonspecific effects at the time of the challenge. Ether stress involved simply placing the rats into a glass chamber saturated with ether vapor. As animals became anesthetized, they were removed from the chamber and exposure was maintained for a total of $5 \mathrm{~min}$ using a nose cone containing ether-soaked cotton. After this, the rats were returned to their home cages where they remained undisturbed until perfusion 0 (control), 5, 15, 30,60,120,180, or $240 \mathrm{~min}$ later. Animals were exposed to stress in subgroups in which at least one animal was killed at each time point.

Perfusion and tissue processing. Animals were perfused under chloral hydrate anesthesia ( $35 \mathrm{mg} / \mathrm{kg}$, i.p.) via the ascending aorta with saline followed by $500 \mathrm{ml}$ of ice-cold $4 \% \mathrm{p}$-formaldehyde in $0.1 \mathrm{M}$ borate buffer, $\mathrm{pH} 9.5$, delivered over $20 \mathrm{~min}$. For pCREB immunocytochemistry, the rats were cannulated $2 \mathrm{~d}$ before stress and were anesthetized for perfusion under stress-free conditions by intravenous administration of anesthetic. The brains were post-fixed in $4 \% p$-formaldehyde with $10 \%$ sucrose for $3 \mathrm{hr}$, then stored overnight in PBS with $10 \%$ sucrose at $4^{\circ} \mathrm{C}$. Five 1-in-5 series of $30-\mu \mathrm{m}$-thick frozen sections through the hypothalamus were cut on a sliding microtome and collected into cryoprotectant, in which they were stored at $-20^{\circ} \mathrm{C}$ until use.

Immunohistochemistry. Fos-immunoreactivity (-ir) was localized using antisera raised in rabbits against a synthetic N-terminal fragment (residues 4-17) of human Fos (Oncogene Sciences, Foster City, CA). Specific staining was abolished by preadsorbing the antiserum overnight at $4^{\circ} \mathrm{C}$ with $50 \mu \mathrm{M}$ of the synthetic peptide immunogen. Affinity-purified antisera raised in rabbit against both the native (unphosphorylated) and phosphorylated forms of pCREB were provided courtesy of Dr. Marc Montminy (The Salk Institute). These were raised against synthetic peptides corresponding to residues 136-150 (native CREB) or a phosphorylated peptide (CREB ${ }^{128-141}$ ) spanning the protein kinase A phosphoacceptor site at $\operatorname{Ser}^{133}$ (Hagiwara et al., 1993). Immunoblot analyses of nuclear extracts from hypothalamus have shown both that purified antisera label a single band of the expected sizc and that only the pCREB antiscrum discriminates unphosphorylated from protein kinase A-phosphorylated CREB (Hagiwara et al., 1993). Staining with the native CREB antiserum was eliminated by overnight preincubation at $4^{\circ} \mathrm{C}$ with $60 \mu \mathrm{M}$ homologous synthetic peptide, whereas that yielded by the anti-pCREB serum persisted after incubation with unphosphorylated $\mathrm{CREB}^{128-141}$ in the low millimolar range. All primary antisera were applied at a 1:1000 dilution and localized using a conventional avidin-biotin immunoperoxidase protocol (Sawchenko et al., 1990) and Vectastain Flite reagents (Vector Laboratories, Burlingame, CA). In addition to anesthetization through intravenous lines to minimize the impact of handling and injection, cmpirically detcrmined modifications incorporated to optimize staining for pCREB included substitution of $3 \%$ BSA for $2 \%$ goat serum as a blocking agent, addition of the phosphatase inhibitors $(1 \mathrm{~mm}$ sodium vanadate and $25 \mathrm{~mm}$ sodium fluoride) to the perfusates and primary antiserum solutions, and carrying out incubations in primary antiserum in the presence of $1 \mathrm{mM}$ unphosphorylated synthetic CREB ${ }^{128-141}$ to minimize nonspecific cross-reactivity.

Hybridization histochemistry. Antisense and sense (control) cRNA probes labeled with $\left[{ }^{35}\right.$ S $]$ uridine triphospate (DuPont NEN, Boston, MA) were used throughout. An AVP hnRNA probe was transcribed from a 700 bp PVUII fragment of intron I of the rat vasopressin gene subcloned into pGEM3 (generously provided by Dr. T. Sherman, University of Pittsburgh). The plasmid was linearized by HindIII and used as a template for in vitro transcription using T7 RNA polymerase. Probes complementary to the single intron of the CRF gene were synthesized from a 500 bp PVUI digest of a rat genomic CRF clone, subcloned into pBluescript transcription vector (Dr. A. Ericsson, The Salk Institute). The identity of the insert was confirmed by partial ( $\sim 250 \mathrm{bp})$ DNA sequence analysis using a commercial kit (Sequenase, United States Biochemicals, Cleveland, $\mathrm{OH}$ ). The plasmid was linearized by BamHI and labeled probes synthesized using T3 polymerase. Full length probes for CRF mRNA (1.2 kb; Dr. K. Mayo, Northwestern University), c-fos mRNA (2,0 kb; Dr. T. Curran, The Roche Institute), NGFI-B mRNA (2.4 kb; Dr. J. Milbrandt, Washington University), and Brn-2 mRNA (1.9 kb; Drs. P. Li and M. G. Rosenfeld, University of California, San Diego) were synthesized as described previously (Chan et al., 1993; Li et al., 1993). All restriction enzymes and RNA polymerases were purchased from Promega (Madison, WI). Free nucleotides were removed by G-50 Sephadex Quick-Spin columns (Boehringer Mannheim, Indianapolis, IN). The specific activities of probes used for analysis were on the order of $1-3 \times 10^{9}$ $\mathrm{dpm} / \mu \mathrm{g}$. In no instance did sense-strand runoffs labeled to similar specific activities yield clear positive hybridization signals in the PVH.

Hybridization and autoradiographic techniques were modified following Simmons et al. (1989). Tissue sections were mounted onto poly-L-lysine-coated slides, post-fixed with $4 \%$ p-formaldehyde for 30 min, then digested with Proteinase $\mathrm{K}(10 \mu \mathrm{g} / \mathrm{ml}$ in $50 \mathrm{~mm}$ Tris, $\mathrm{pH} 8$, and $5 \mathrm{~mm}$ EDTA at $\left.37^{\circ} \mathrm{C}, 30 \mathrm{~min}\right)$, acetylated $(0.25 \%$ acetic anhydride in 0.1 $\mathrm{M}$ triethanolamine, $\mathrm{pH} 8)$, and dehydrated. Hybridization mixture $(100$ $\mu \mathrm{l}$; containing probe $10^{7} \mathrm{dpm} / \mathrm{ml}$ ) was pipetted onto the slides, which were then coverslipped, sealed, and incubated overnight at $56^{\circ} \mathrm{C}$. Coverslips were removed, and sections were rinsed in $4 \times$ SSC $(1 \times$ SSC, $0.15 \mathrm{M}$ $\mathrm{NaCl}$ and $15 \mathrm{~mm}$ trisodium citrate buffer), then digested with ribonuclease A $\left(20 \mu \mathrm{g} / \mathrm{ml}\right.$ in Tris-EDTA buffer with $0.5 \mathrm{M} \mathrm{NaCl}$ at $\left.37^{\circ} \mathrm{C}, 30 \mathrm{~min}\right)$, gradually desalted, and washed in $0.1 \times \mathrm{SSC}$ at $65-75^{\circ} \mathrm{C}$ for $30 \mathrm{~min}$. Slides were exposed to x-ray film for $24-48 \mathrm{hr}$, then dipped in NBT2 nuclear emulsion (Kodak) and exposed for intervals ranging from 8 to $10 \mathrm{~d}$ (CRF and c-fos mRNAs and AVP hnRNA) to 6 weeks (CRF hnRNA), developed in D-19 developer (Kodak, Rochester, NY), and lightly counterstained with thionine.

Combined immunohistochemistry and hybridization histochemistry. To determine the extent to which the multiple markers used here identified a common population of neurons in the parvocellular division of the PVH, concurrent localization of pCREB- or Fos-ir with CRF or AVP hnRNA, or c-fos mRNA was carried out using a variant (Chan et al., 1993) of a procedure described by Watts and Swanson (1989). In brief, immunolocalization of Fos- or pCREB-ir was carried out as described above, except that the tissue was not pretreated in borohydride or hydrogen peroxide. In addition, the primary antibody reaction was performed in buffer with $3 \%$ BSA as a blocking agent (in place of nonimmune goat serum) and $2.5 \mathrm{mg} / \mathrm{ml}$ heparin sulfate (to inhibit 


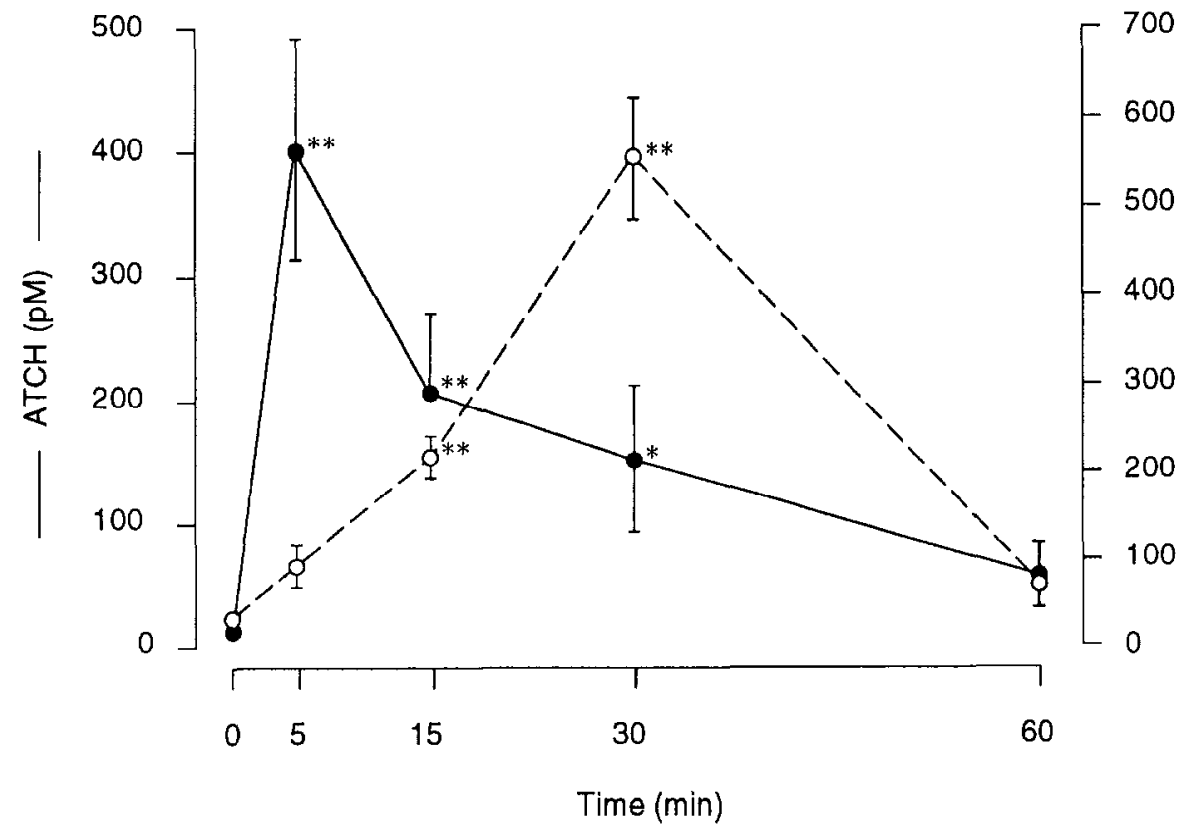

Figure 1. Mean $( \pm$ SEM) plasma ACTH and corticosterone concentrations at various time points after 5 min exposure to ether vapor $(n=5)$. ${ }^{*} p<0.05 ;{ }^{* *} p<0.01$ vs nonstimulated $(0 \mathrm{~min})$ values.

RNase activity), and the reaction product was developed without nickel enhancement. Subsequent localization of a select RNA species by in situ hybridization was then carried out as described above.

Analysis. Semiquantitative densitometric analysis of relative levels of RNAs of interest was carried out on nuclear emulsion-coated slides. The basic procedure involved preparation of brain paste standards containing serial dilutions of $\left[{ }^{35} \mathrm{~S}\right] \mathrm{UTP}$, which were sectioned in a cryostat at the same thickness as the experimental material, collected on slides, and fixed with $p$-formaldehyde in the vapor phase at $60^{\circ} \mathrm{C}$. Unfixed sections adjacent to these were counted in a liquid scintillation counter. A standard curve was generated by selecting the curve of best fit that related the optical density of the brain paste standards to the amount of radioactivity per unit area of the standard. Densitometric analysis of autoradiographic images was carried out using Macintosh-driven National Institutes of Health Image software (version 1.55). Slides were coded for analysis to obscure treatment status. The medial parvocellular subdivision of the PVH (Swanson and Kuypers, 1980) was defined from Nissl staining patterns and aligned with corresponding dark-field images of hybridized sections by redirected sampling. Optical density readings, corrected for background, were taken at regularly spaced $(100 \mu \mathrm{m})$ intervals, and average values were determined throughout the extent of this cell group (3-5 sections) for each animal. Relative levels of CRF hnRNA and mRNA, and of AVP hnRNA, thus were compared as a function of time after stress.

Because densitometric measures of AVP hnRNA in the medial parvocellular part of the PVH are complicated by the presence of scattered magnocellular neurosecretory neurons in this region that express high levels of AVP hnRNA and mRNA under basal conditions (see Sawchenko et al., 1993; Herman, in press), and because this has implications for comparing the time courses of CRF and AVP transcriptional activation in response to stress, a second approach to quantitation was used. This involved simply counting the number of nuclei in the medial parvocellular part of the PVH overlaid by clusters of reduced silver grains, the density of which was $>5$ times that of background, as determined by counting grains over non-CRF- or non-AVP-expressing hypothalamic cells (dorsomedial nucleus) of comparable size and packing density. Abercrombie's (1946) method was used to correct for doublecounting errors.

Data from all measures are expressed as mean \pm SEM and were analyzed by one-way ANOVA (Instat software, Waltham, MA) and Dunn's post-hoc test for multiple pairwise comparisons.

\section{RESULTS}

\section{Hormone secretion}

To provide comparisons for the timing of effects exerted at a cellular level in neurosecretory neurons, hormonal response pro- files were obtained in a separate group of five cannulated rats. After acute, 5 min exposure to ether vapor, plasma ACTH concentrations increased rapidly from baseline values of $12 \pm 5$ to a peak of $400 \pm 88 \mathrm{pm}$ within $5 \mathrm{~min}$, then declined to resting levels between 30 and $60 \mathrm{~min}$ (Fig. 1). Plasma corticosterone levels rose more gradually to reach a maximum at 30 min after stress $(>500$ $\mathrm{nM}$ ) and by $60 \mathrm{~min}$ did not differ significantly from basal levels ( 24 $\pm 7 \mathrm{nM}) . \Lambda$ group of nonstressed rats examined in parallel displayed $\mathrm{ACTH}$ and corticosterone levels that remained within the range of baseline values throughout the 2 hr blood-sampling period (data not shown).

\section{Neuroendocrine hnRNA and mRNA responses}

Intron-specific cRNA probes were used to assess stress-induced changes in the transcriptional activation of the CRF and AVP genes. These probes hybridize to sequences in heteronuclear RNA before processing to mRNA and, therefore, provide an index of transcriptional activation (Herman et al., 1991, 1992). Under resting conditions, CRF hnRNA expression is low, and only a few neurons of the parvocellular PVH displayed a weak nuclear hybridization signal (Fig. 2). Ether exposure provoked a marked and surprisingly rapid increase in CRF hnRNA that peaked at $5 \mathrm{~min}$ after stress, the time of the maximal $\mathrm{ACTH}$ secretory response. This response was diminished in animals killed at $30 \mathrm{~min}$ and was not evident in those examined at 1-4 hr after exposure (Figs. 2, 3). Throughout the time course examined, cells in the PVH that exhibited a CRF hnRNA signal remained overwhelmingly localized to the hypophysiotropic (dorsal medial parvocellular) compartment. Because of concerns as to whether the low basal level of expression biased the view provided by densitometric assessments of the population's responses, counts were generated of the number of neurons evincing a positive nuclear hybridization signal in the medial parvocellular part of the $\mathrm{PVH}$ as a function of time after stress (Table 1). These provided a similar view of the timing of ether effects on CRF hnRNA, with a maximal 4.7-fold increase in the number of cells detectable at 5 min after stress, diminishing to values that were no longer significantly elevated above controls by $2 \mathrm{hr}$ after the challenge. 

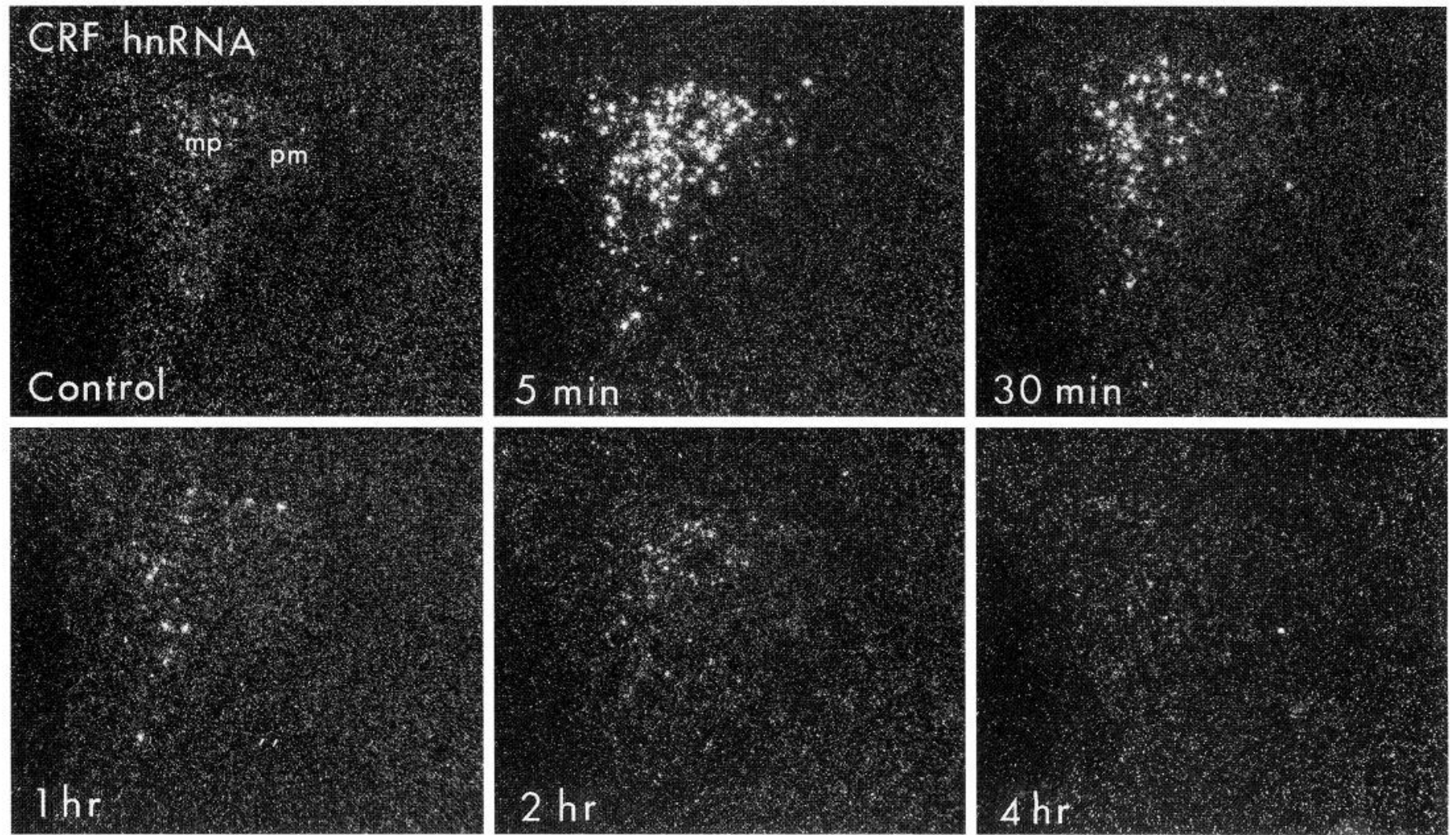

Figure 2. Time course of CRF hnRNA responses to ether. Dark-field autoradiograms showing nuclear hybridization signal obtained using an intron-specific cRNA probe at key poststress time points. A similar rostro-caudal level of the PVH is shown in all photomicrographs; the third ventricle is at the left. Expression of CRF hnRNA is maximal at 5 min after stress and is limited mostly to the medial parvocellular $(\mathrm{mp}$ ) subdivision of the PVH throughout the time course examined. Positively hybridized cells were rare in the posterior magnocellular (pm) part of the PVH at all time points. All photomicrographs $75 \times$ magnification.

Despite robust increases in the relative levels of, and number of cells expressing, CRF hnRNA, densitometric assessments of CRF mRNA revealed no significant elevation over control levels at any poststress time point examined ( $p>0.10$; Fig. 3).

In contrast to the situation with the primary CRF transcript, basal expression of AVP hnRNA was evident in major acknowledged sites of AVP synthesis in the hypothalamus, including magnocellular neurosecretory neurons of the PVH and supraoptic nucleus, as well as in the suprachiasmatic nucleus. Nonstressed rats did not display a discernible AVP hnRNA signal in the parvocellular subdivision of the PVN, over and above what could be attributed to ectopic magnocellular neurosecretory neurons that are reliably scattered throughout this compartment (Fig. 4). Densitometric analysis indicated that ether stress-induced changes in AVP hnRNA expression are slower in onset than those in the primary CRF transcript. Reliable increases in the AVP intronic signal over the parvocellular $\mathrm{PVH}$ were detected at $1 \mathrm{hr}$ after ether exposure, were maximal at $2 \mathrm{hr}$, and were not significantly elevated above those of nonmanipulated controls at $4 \mathrm{hr}$ after stress (Figs. 3, 4). Parallel assessments of the number of cells in the hypophysiotropic (medial parvocellular) part of the PVH displaying positive signals for the nascent AVP transcript were fully compatible with the population responses, with peak values achieving 3.2 times the number of cells detected in controls at $2 \mathrm{hr}$ after stress (Table 1). By contrast, no significant changes were found in the levels of hybridizable AVP hnRNA over the magnocellular division of the PVH throughout the $4 \mathrm{hr}$ poststress period (data not shown).

\section{Transcription factor responses}

The IEGs c-fos and NGFI-B have been used widely as inducible markers of cellular activation in stress-related neural circuitry within and beyond the endocrine hypothalamus. The course of their ether-induced appearance in the PVH was similar to that seen in response to other acute stressors, although it was somewhat accelerated (Fig. 5). From baseline levels within the PVH that ranged from undetectable to weak labeling of a few scattered cells, c-fos mRNA induction first appeared at 15 min after stress in the parvocellular division of the nucleus. The hybridization signal reached its maximum in most cases at $30 \mathrm{~min}$, was diminished by $1 \mathrm{hr}$, and was consistently not discriminable from controls at 2-4 hr after stress. The c-fos protein product, Fos, was localized by immunohistochemistry using an $\mathrm{N}$-terminally directed antiserum that is not known to cross-react with Fos-related antigens. Compatible with the mRNA results, ether stress induced nuclear Fos-ir in the parvocellular neurosecretory compartment of the $\mathrm{PVH}$ in a highly preferential manner, with maximal staining intensity and cell number seen at $1 \mathrm{hr}$ or, less frequently, $2 \mathrm{hr}$ after stress in different cohorts of animals. In all repetitions of the experiment, Fos-ir labeling in the PVH of animals killed at $4 \mathrm{hr}$ was not distinguishable from that seen in controls. For purposes of comparison with other stress models, extrahypothalamic loci of ether-induced Fos expression were numerous, although not promiscuously so. These included aspects of the main olfactory bulb and piriform cortex, components of the limbic region of the telencephalon such as the lateral septal nuclei, bed nucleus of stria 

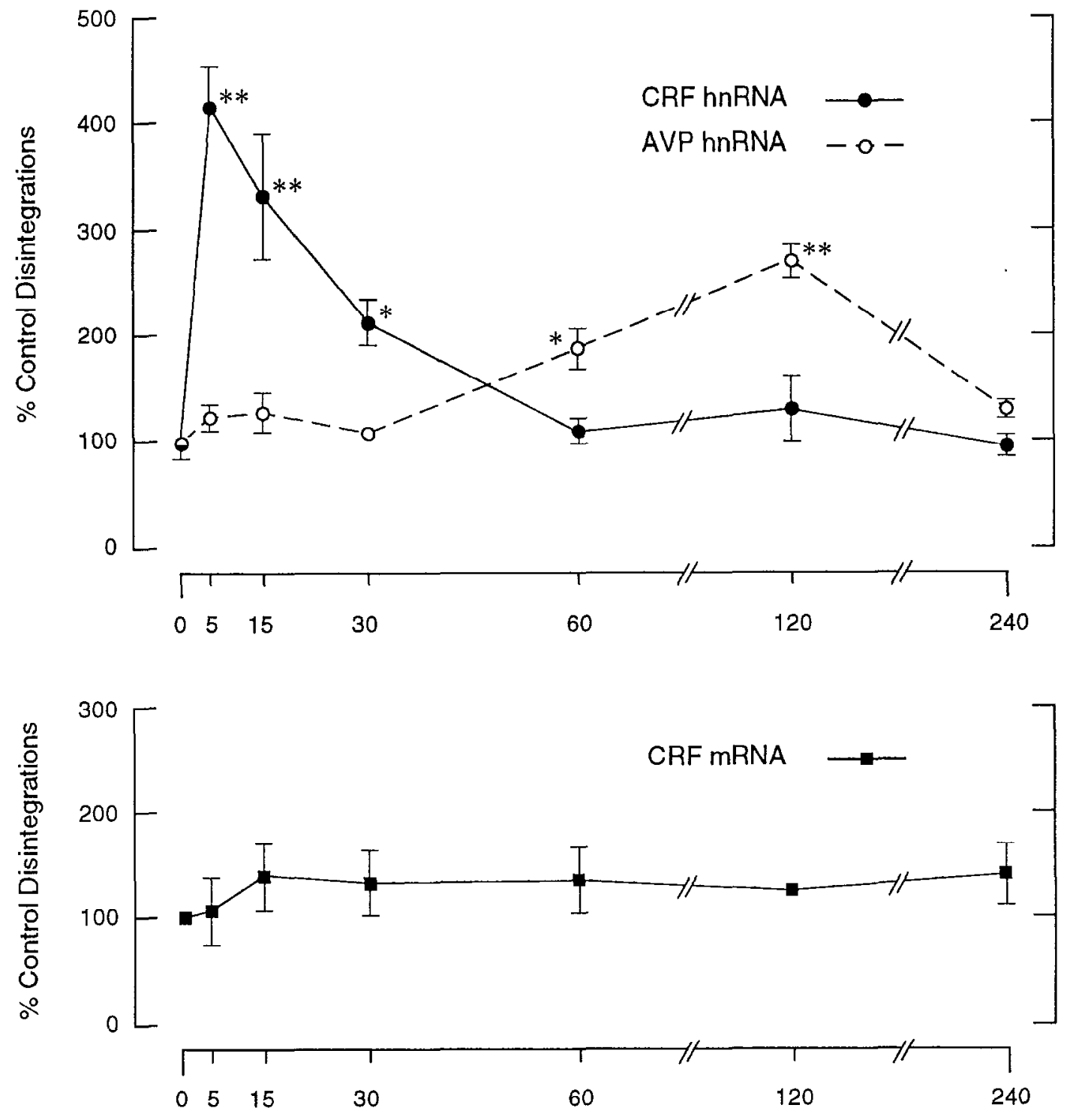

Min After Stress

Figure 3. Relative levels of CRF and AVP hnRNA (top) and CRF mRNA (bottom) at select intervals after 5 min exposure to ether. Values are based on densitometric determinations and are given as mean \pm SEM percentage of control values $(n=3-8$ rats/time point). Data points lacking error bars reflect means with SEMs that are less than the value represented by the height of symbol used to depict them. ${ }^{*} p<0.05$; ${ }^{* *} p<0.01$ vs nonstressed controls.

terminalis, central and medial nuclei of the amygdala, cingulate, pre- and infralimbic cortices, several midline and intralaminar nuclei of the thalamus, periaqueductal gray, nucleus of the solitary tract, ventrolateral medulla, and locus coeruleus.

As reported previously (Chan et al., 1993), constitutive expression of NGFI-B mRNA was evident throughout broad expanses of the telencephalon (including iso- and hippocampal cortices and the caudoputamen), but not in the PVH under resting conditions (Fig. 5). No alterations in NGFI-B at the earliest $(5 \mathrm{~min}$ ) time point were seen in any experiment, but expression increased thereafter to reach peak levels between $30 \mathrm{~min}$ and $1 \mathrm{hr}$ after ether exposure, once again being localized principally to the

\begin{tabular}{|c|c|c|c|c|c|c|c|}
\hline \multirow[b]{2}{*}{ Probe $(n)$} & \multirow[b]{2}{*}{ Control } & \multicolumn{6}{|c|}{ Time after stress } \\
\hline & & $5 \mathrm{~min}$ & $15 \mathrm{~min}$ & $30 \mathrm{~min}$ & $1 \mathrm{hr}$ & $2 \mathrm{hr}$ & $4 \mathrm{hr}$ \\
\hline CRF hnRNA & $120 \pm 11(4)$ & $568 \pm 44^{*}(6)$ & $483 \pm 35^{* *}(3)$ & $240 \pm 21^{* *}(4)$ & $179 \pm 29^{*}(5)$ & $78 \pm 22(4)$ & $111 \pm 19(4)$ \\
\hline AVP hnRNA & $162 \pm 27(4)$ & $147 \pm 17(4)$ & $207 \pm 21(3)$ & $186 \pm 13(3)$ & $392 \pm 30^{* *}(5)$ & $523 \pm 38^{* *}(5)$ & $210 \pm 36(4)$ \\
\hline
\end{tabular}

Differs significantly from respective control values: ${ }^{*} p<0.05 ;{ }^{* *} p<0.01$. 

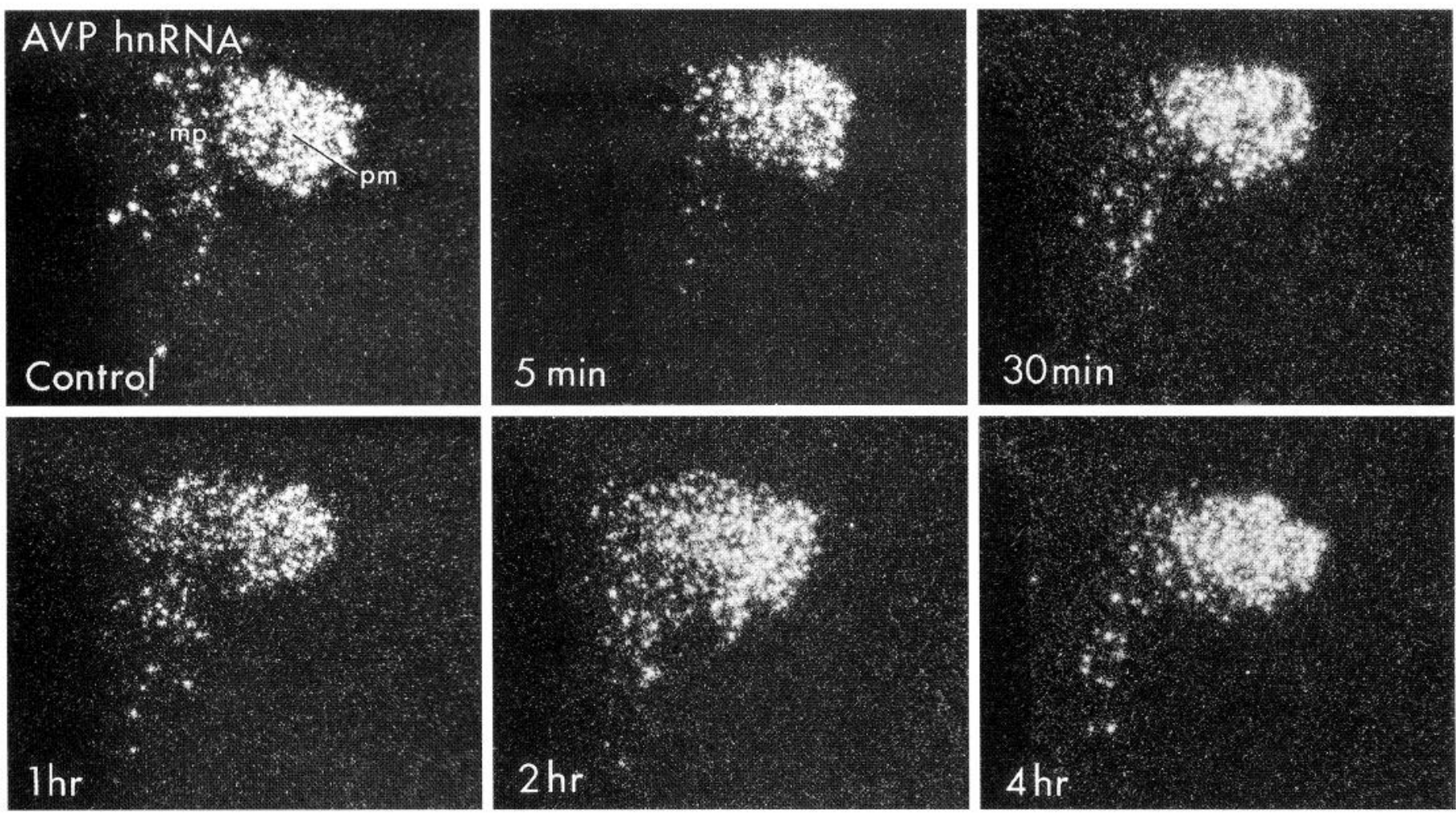

Figure 4. Time course of AVP hnRNA responses to ether. Dark-field autoradiograms showing nuclear hybridization signal obtained using a cRNA probe specific to the first intron of the AVP gene at key poststress time points. Basal levels of expression are significant in the magnocellular division of the PVH $(\mathrm{pm})$ and in scattered cells of the parvocellular division $(\mathrm{mp})$ that correspond presumably to ectopic magnocellular neurosecretory neurons. In response to ether, a reliable increase in the number of positively hybridized cells in the parvocellular division is apparent at $1 \mathrm{hr}$, and is maximal at $2 \mathrm{hr}$, after stress. No frank alteration in the strength or distribution of hybridization signal over the magnocellular division is apparent over the time points sampled. All photomicrographs $75 \times$ magnification.

CRF-rich zone of the parvocellular division of the PVH. The NGFI-B mRNA response was diminished markedly by $2 \mathrm{hr}$ and was not evident in animals killed at $4 \mathrm{hr}$ after the challenge.

mRNA encoding the POU-domain factor Brn-2 was found to be constitutively expressed throughout both the parvocellular and magnocellular neurosecretory compartments of the PVH (Fig. 6), as well as in the supraoptic nucleus; these were the only hypothalamic loci of Brn-2 mRNA expression that were detectable under basal or stimulated conditions. Nevertheless, neither apparent nor measured effects on Brn-2 mRNA were evident at any time point examined after ether stress $(p>0.10)$.

CREB has been implicated in the transcriptional regulation of the immediate-early gene c-fos and of both the CRF and AVP genes (see Discussion). Immunohistochemical localization studies were used to identify and follow any stress-induced alterations in the abundance of native (unphosphorylated) CREB and pCREB. Native CREB was found to be expressed constitutively in ostensibly all neuronal nuclei in the PVH and, indeed, throughout all brain regions examined (Fig. 7); exposure to ether resulted in no obvious or consistent changes in the number or staining intensity of CREB-ir neurons or in the compartmental localization of reaction product. Affinity-purified antisera specifically recognizing the $\operatorname{Ser}^{133}$-phosphorylated form of CREB revealed a much lesser and much less ubiquitous basal expression of pCREB that responded dynamically to an ether challenge (Fig. 7). Nonstressed rats displayed a weak pCREB signal in a number of telencephalic structures (including aspects of the neocortex, hippocampal formation, and basal ganglia), as well as some diencephalic ones. The latter included midline thalamic nuclei and the magnocellular, but not the parvocellular, division of the PVH. Reliable induction of pCREB-ir was detected within the parvocellular division of the $\mathrm{PVH}$ at $5 \mathrm{~min}$ after ether exposure. Nuclear staining in animals killed at this early time point was weak but involved numerous cells within the division. Animals killed at $15 \mathrm{~min}$ poststress displayed a maximally intense pCREB-ir signal by neurons of the parvocellular $\mathrm{PVH}$, without any further apparent increase in the number of positively stained nuclei. This response diminished progressively (in both staining intensity and cell number) at $30 \mathrm{~min}$ and $1 \mathrm{hr}$ after stress and was not detectable from $2 \mathrm{hr}$ onward. No ether-induced alterations in the number or staining intensity of pCREB-ir cells in the magnocellular neurosecretory system were apparent at any time point after stress. Extrahypothalamically, several cortical structures, particularly the piriform and anterior cingulate cortices, displayed comparably transient increases in the number and staining intensity of pCREB-ir neurons after stress.

To determine the extent to which the populations of cells within the parvocellular division of the PVH that manifest etherinduced pCREB- or Fos-ir responses conformed to CRF- and/or AVP-expressing parvocellular neurons, or to one another, series of sections through the $\mathrm{PVH}$ from animals killed at appropriate time points were prepared for concurrent immunohistochemical and hybridization histochemical localization (Fig. 8). Tissue from animals $(n=3)$ killed at $5 \mathrm{~min}$ after stress revealed a maximum of $72 \%$ of all pCREB-ir nuclei in the medial parvocellular 

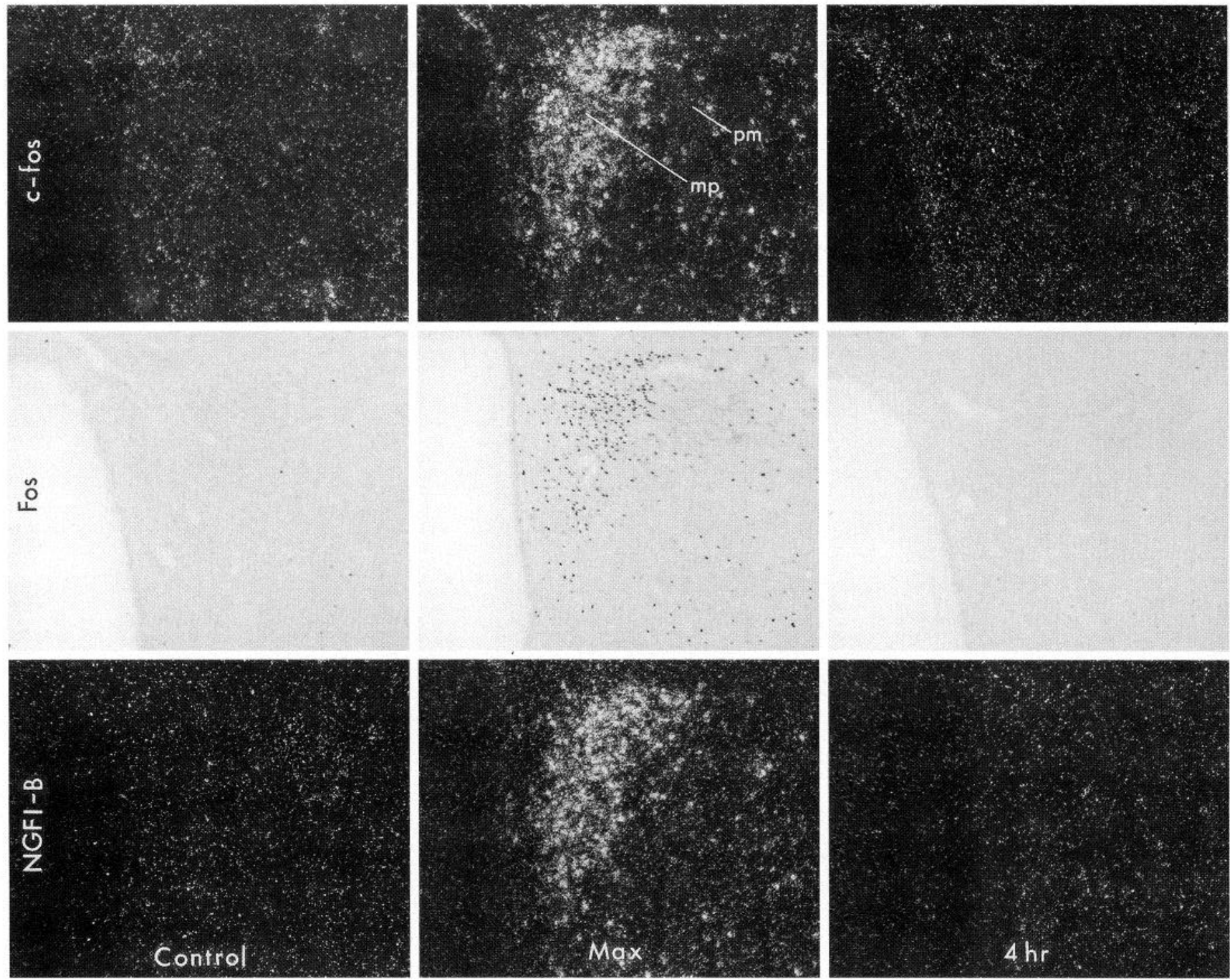

Figure 5. Ether-induced immediate-early gene expression. Photomicrographs taken through a comparable level of the PVH showing the distribution and relative strength of c-fos (top) and NGFI-B (bottom) mRNA signals, and Fos immunoreactivity (middle) in control animals (left) and in rats killed at either the time of maximal expression of these markers (Max; middle) or at $4 \mathrm{hr}$ after stress (bottom), the latest time point examined. Maximal IEG mRNA expression (at 30 or $60 \mathrm{~min}$ ) and Fos protein expression (at 60 or $120 \mathrm{~min}$ ) were both preferentially localized to the hypophysiotropic (medial parvocellular; $\mathrm{mp}$ ) part of the PVH and included little, if any, involvement of magnocellular neurosecretory neurons in the posterior magnocellular ( $\mathrm{pm}$ ) subdivision. All photomicrographs $75 \times$ magnification.

part of the PVH also overlaid by a positive hybridization signal for CRF hnRNA; a comparable fraction (78\%) of all CRF hnRNA-positive cells in this compartment exhibited pCREB-ir in this same experiment. A similar sampling of animals killed at $2 \mathrm{hr}$ after ether exposure resulted in as much as $63 \%$ of all Fos-ir nuclei decorated with reduced silver grains resulting from hybridization with the AVP intronic probe. Finally, dual localization of pCREB-ir and c-fos mRNA in animals killed at 15 min after ether exposure revealed highly concordant patterns of expression, $83 \%$ of all immunostained neurons displaying a positive hybridization signal in the best of three experiments.

\section{DISCUSSION}

We have provided an overview of the sequence of cellular events associated with the ether stress-induced activation of the central limb of the hypothalamic-pituitary-adrenal axis (Fig. 9). Early in this progression a rapid burst of CRF gene transcription occurs, evidenced by elevated expression of the cognate primary transcript. This was paralleled by phosphorylation of transcription factor CREB in these very neurons. By contrast, ether-induced upregulation of AVP hnRNA was delayed, occurring in step with events that require de novo protein synthesis, including induced IEG expression. These results constrain the search for mechanisms underlying stress-induced transcriptional activation of genes encoding major ACTH secretagogues in hypophysiotropic neurons and address general issues associated with the now pervasive use of transcription factors to provide generic indices of cellular activation in brain.

\section{Biosynthetic responses of hypophysiotropic neurons}

Multiple independent markers suggest a preferential activation of parvocellular neurosecretory neurons of the PVH after ether exposure. This paradigm, therefore, may be useful for exploring the mechanisms governing the synthesis and release of the 

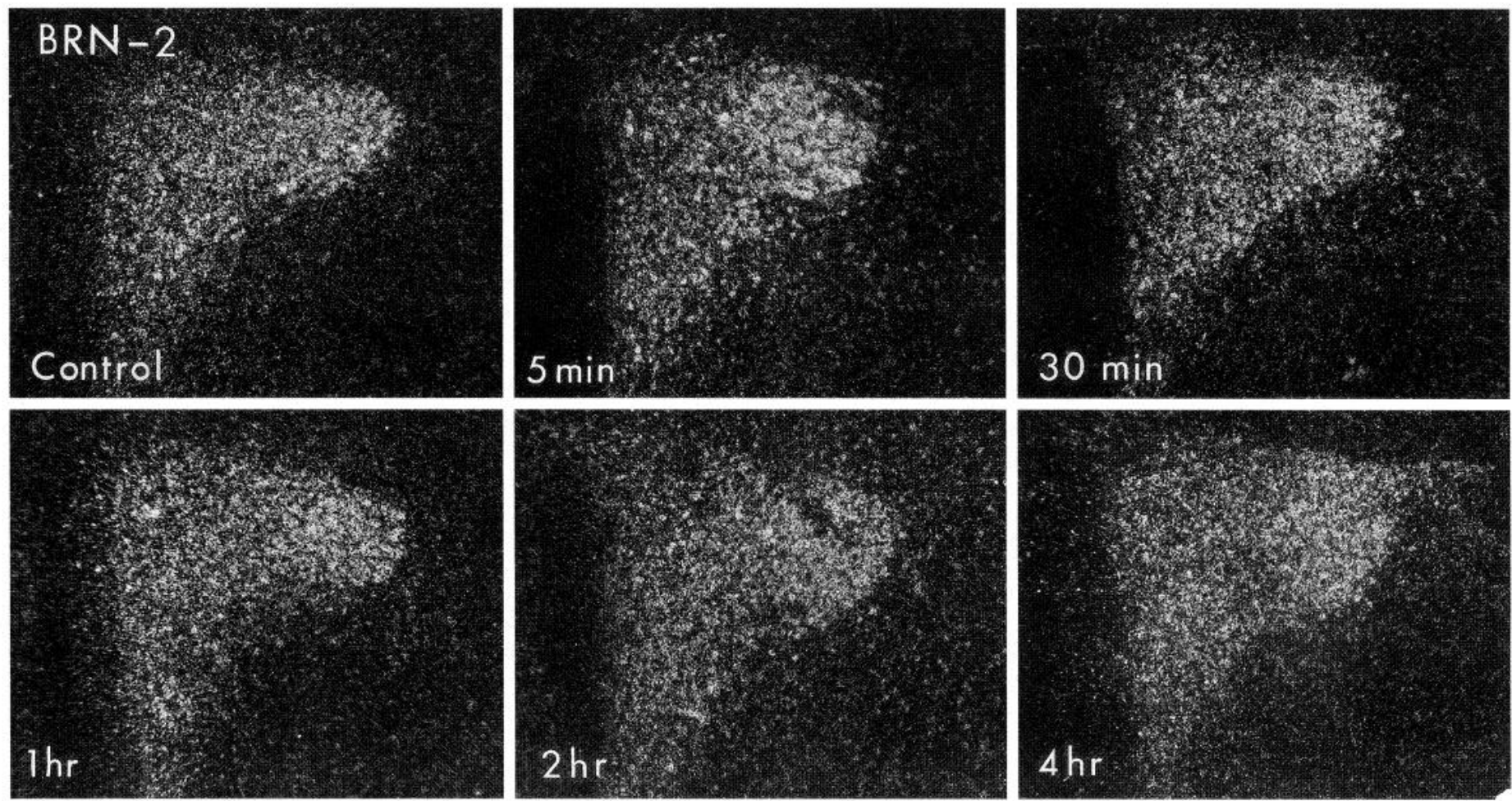

Figure 6. Absence of acute ether stress effects on Brn-2 mRNA in the PVH. Dark-field autoradiograms show hybridization signal for Brn-2 mRNA at key poststress time points. This transcript is expressed broadly and consitutively in both the parvocellular and magnocellular compartments of the PVH. No alterations in the expression of Brn- 2 mRNA were evident over the range of poststress time points examined. All photomicrographs $75 \times$ magnification.
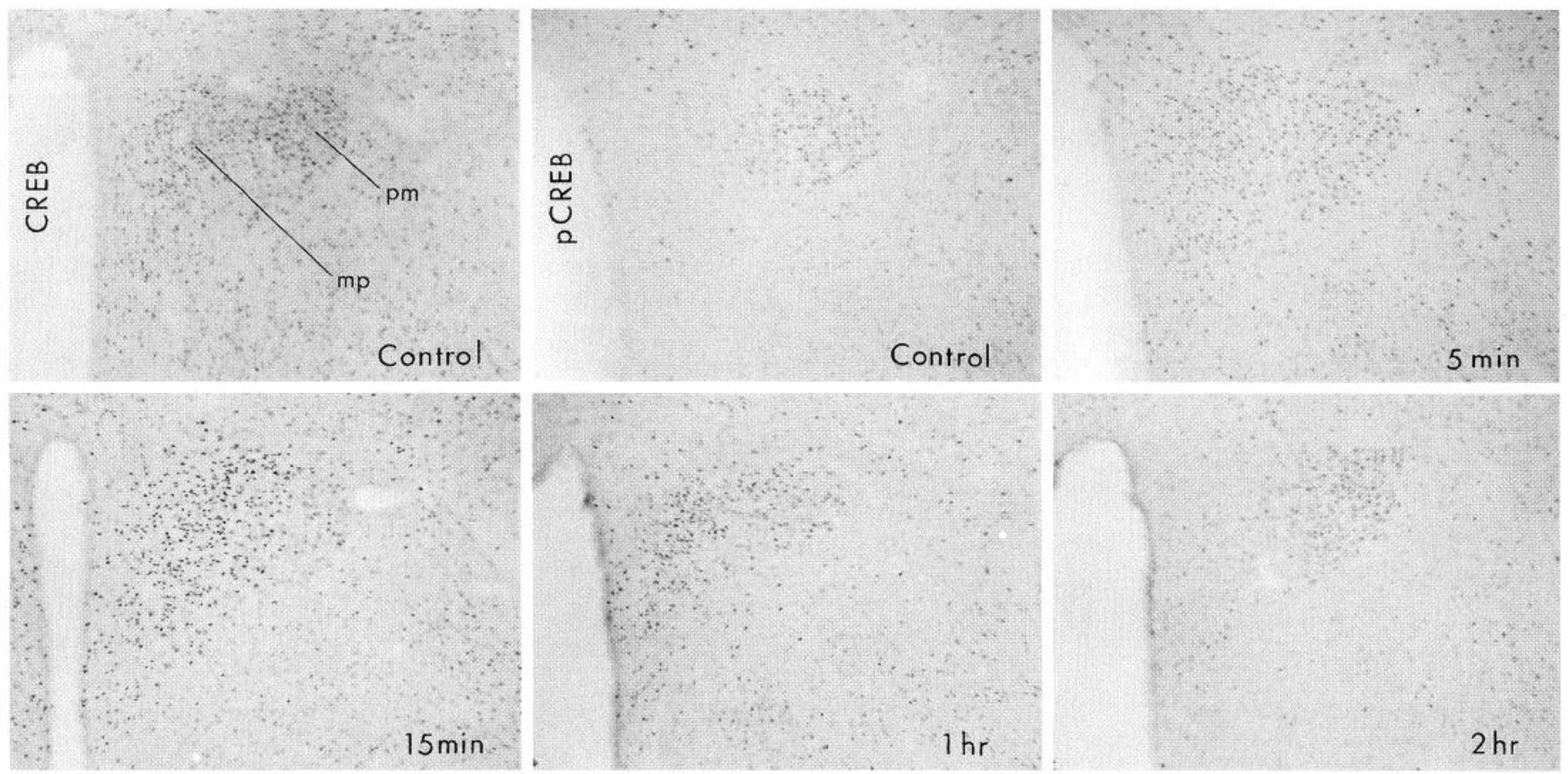

Figure 7. Time course of pCREB responses to stress. Bright-field photomicrographs of sections through a level of the PVH from a control rat stained with an antiserum against native CREB (top left) and from animals killed at varying intervals after 5 min exposure to ether and stained with an antiserum specific to the pCREB. CREB antisera ubiquitously stain neuronal nuclei throughout the PVH and elsewhere, whereas under control conditions low levels of basal pCREB are evident in the posterior magnocellular $(\mathrm{pm})$, but not the medial parvocellular $(\mathrm{mp})$, part of the PVH. Ether exposure results in a rapid appearance of low level pCREB-ir in the parvocellular division 5 min after stress, which achieves peak intensity at 15 min, and declines thereafter to a pattern approximating that seen in controls by $2 \mathrm{hr}$ after the challenge. pCREB-ir in the magnocellular division remains relatively constant over the time course examined. Magnifications, $75 \times$ 


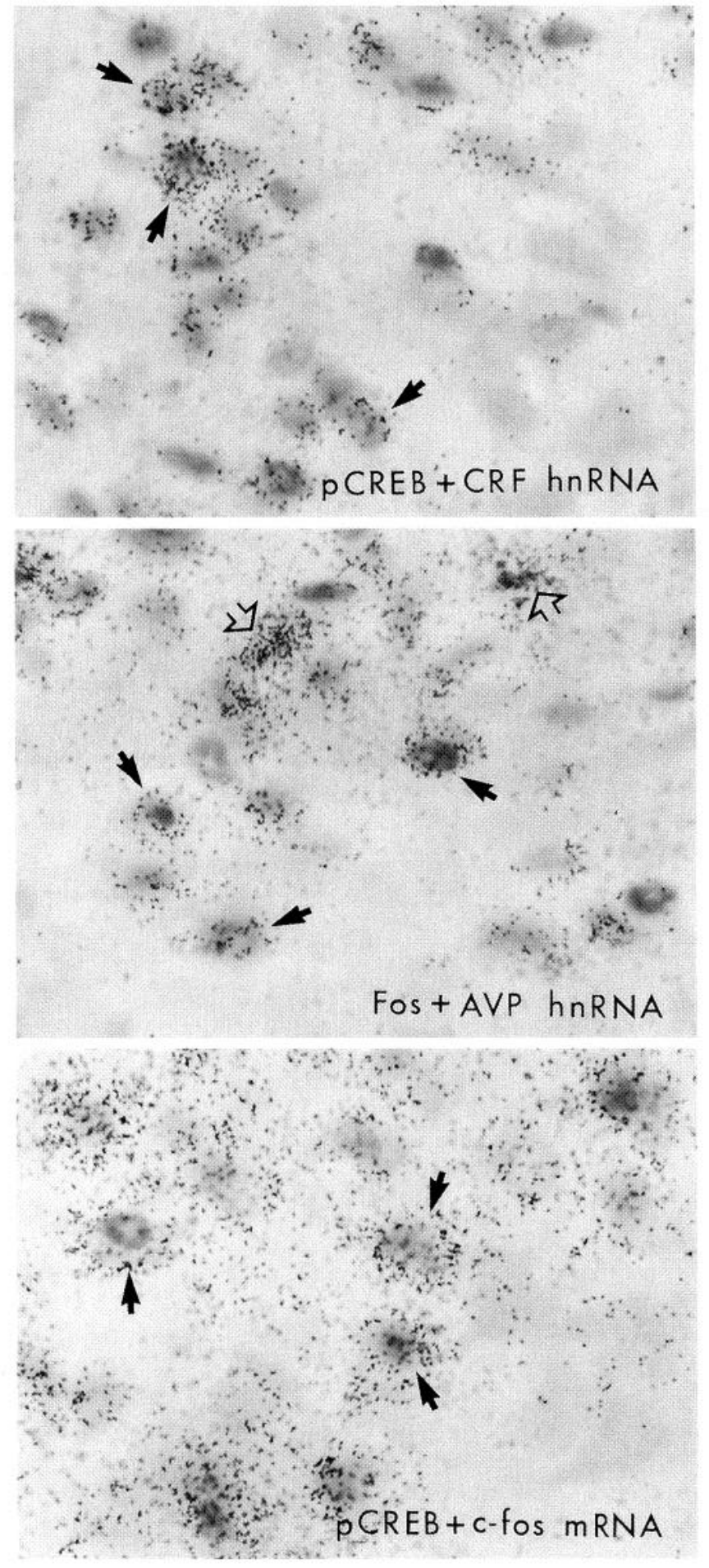

Figure 8. Dual localization of transcription factor markers and/or hnRNAs in hypophysiotropic neurons. Bright-field photomicrographs of fields in the medial parvocellular subdivision of the PVH. Top, pCREB-ir nuclei (gray) and reduced silver grains indicative of CRF hnRNA signal from a rat killed at 5 min after stress. Middle, Fos-ir nuclei and AVP hnRNA signal from an animal killed at $2 \mathrm{hr}$ after stress. Bottom, pCREB-ir nuclei and c-fos mRNA signal from an animal killed at 15 min after stress. In all instances, black arrows identify examples of cells displaying both markers. Open arrows in the middle panel show larger clusters of reduced silver grains not associated with Fos-ir nuclei, which may correspond to nuclei of ectopic magnocellular neurosecretory neurons. Note the relatively tight clustering of reduced silver grains in the hnRNA preparations around neuronal nuclei (top two panels), which contrasts with the more distributed (cytoplasmic) pattern of c-fos mRNA (bottom). All photomicrographs $750 \times$ magnification. two major synergistically interacting ACTH cosecretagogues, uncomplicated by any major involvement of the magnocellular neurosecretory system. Previous work has established that probes complementary to intronic sequences of the CRF (Herman et al., 1992) and AVP (Young et al., 1986; Herman et al., 1991) genes provide assessments compatible with direct estimates of transcription rate by nuclear run-on assays, thus validating a means to characterize effects exerted at the transcriptional level in vivo. The limited time course data available using such probes describe maximal increases of CRF hnRNA at 30 min after steroid synthesis blockade (Herman et al., 1992) and of AVP hnRNA in the parvocellular PVH at 30-60 min in response to acute restraint stress (Herman, in press). Elevated AVP hnRNA has been reported in the PVH as late as $120 \mathrm{~min}$ after exposure to an open-field situation (Priou et al., 1993). In comparing here for the first time CRF and AVP hnRNA responses of parvocellular neurons to a common challenge, we detect stark differences in the timing of peak CRF ( $5 \mathrm{~min})$ and AVP (120 min) hnRNA responses, as revealed by both population densitometry and cell counts. The congruence of cells evincing hnRNA and/or temporally contiguous transcription factor responses suggests that these markers identify a common population of hypophysiotropic neurons. Although the generality of the temporal profiles we describe is uncertain, the results support an involvement of distinct mechanisms underlying stress effects on CRF and AVP expression and emphasize the need for time course studies to specify targeted genes and cell types veridically in a given paradigm.

Despite robust increases in primary CRF and AVP transcripts in hypophysiotropic neurons, we failed to detect a reliable upregulation of CRF mRNA at any time point. Watts (1991) has also reported a failure of ether exposure to increase CRF mRNA in the PVH. This could be attributable to technical factors, where the substantial basal pool of CRF mRNA may limit, by dilution, the ability to detect subtle increases and/or to concurrent alterations in RNA processing or stability. Little is known of the extent to which alterations in secretion, axonal transport, transcription, and post-transcriptional processing events are regulated coordinately versus independently and, consequently, whether changes in one of these parameters are necessarily predictive of alterations in others. In light of this uncertainty, it seems reasonable to conclude only that detectable alterations in CRF and/or AVP mRNA are a common (for reviews, see Harbuz and Lightman, 1992; Whitnall, 1993), but not a necessary, concomitant to transcriptional activation.

The IEGs NGFI-B and, particularly, c-fos have been shown to provide reliable markers of hypothalamic neurons and extended circuitries that are recruited to activation in a variety of acute stress paradigms (Ceccatelli et al., 1989; Chan et al., 1993; Hoffman et al., 1993). Ether-induced IEG mRNA and Fos protein responses were somewhat accelerated, relative to the peaks at $\sim 1$ and $\sim 2 \mathrm{hr}$, respectively, commonly reported in other acute challenge situations (Herman et al., 1992; Imaki et al., 1992; Chan et al., 1993; Ericsson et al., 1994) (see Fig. 9). The stress-induced appearance of pCREB was more rapid still, appearing within 5 min and peaking at $15 \mathrm{~min}$ after ether exposure. Comparably prompt pCREB responses have been described in the PVH after hypertonic saline injection (Borsook et al., 1994) and in the suprachiasmatic nucleus after exposure to light in specific circadian contexts (Ginty et al., 1993). 
Figure 9. Sequence of cellular events in the ether stress-induced activation of parvocellular neurosecretory neurons. Schematic summary, based on the present findings, showing the approximate timing of various indices of synaptic and/or transcriptional activation in the hypophysiotropic CRF neuron. The early events include a rapid and transient generation of the primary CRF transcript, which proceeds roughly in step with increased phosphorylation of transcription factor CREB. IEG mRNA and protein responses occur considerably later, with the latter contemporaneous with maximal stress-induced increases in the AVP hnRNA. Although not detected in the present experiments, stressinduced increases in CRF and/or AVP mRNA are also commonly reported $2-3 \mathrm{hr}$ after acute exposure.

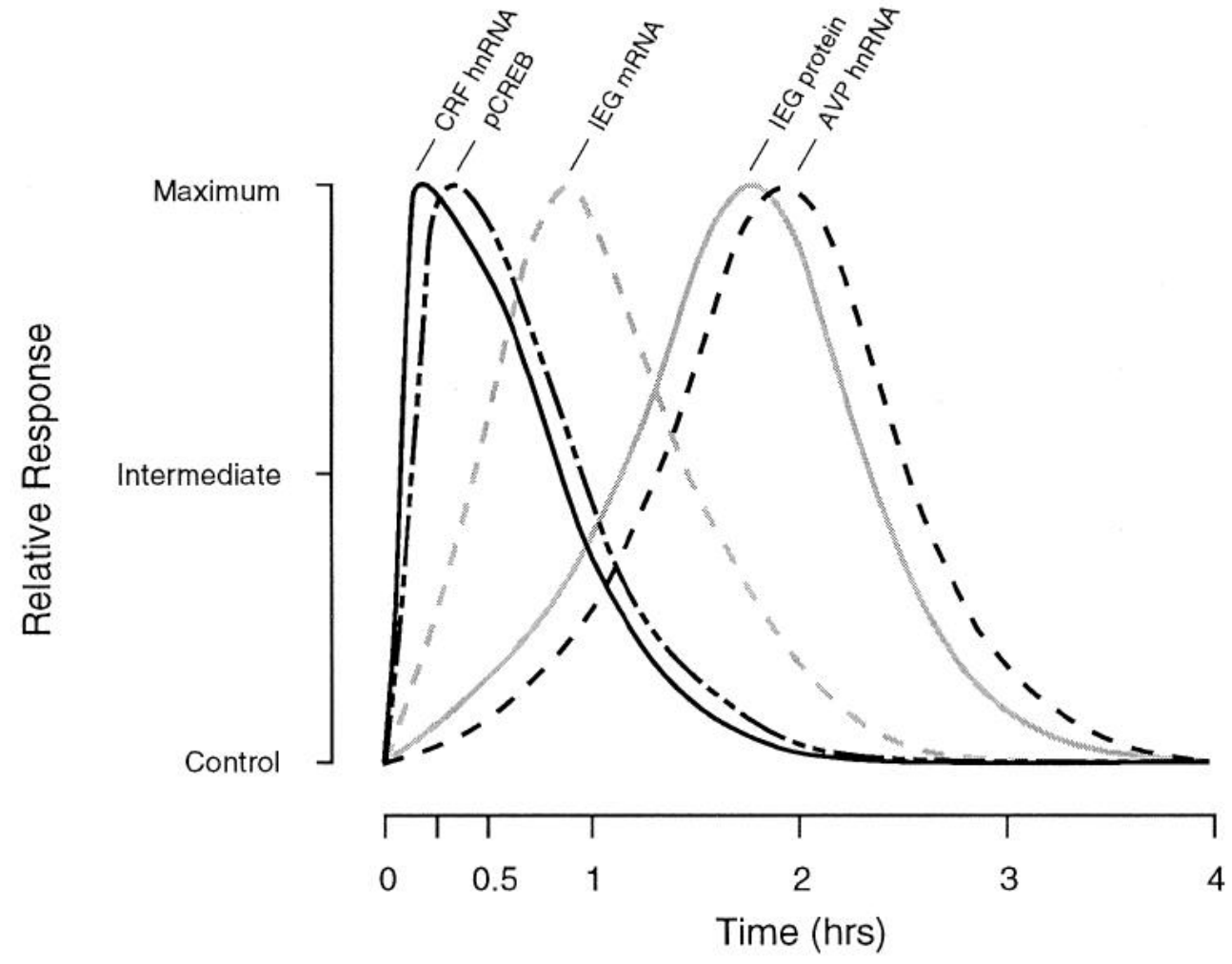

AVP gene contains sequences resembling canonical CRE, aminopyridine-1 (AP-1), and NGFI-B response elements, each of which could play a role in translating stress-related sensory input into altered AVP expression. Evidence that the AVP promoter possesses two functional CREs (Pardy et al., 1992), and that activators of cAMP enhance AVP mRNA levels in vitro (Verbeeck et al., 1990), support an involvement of pCREB or ATF transcription factors. The bases for our observation that elevated AVP hnRNA is not detectable until nuclear pCREB is in sharp decline are not clear at this time. Parvocellular neurons of the $\mathrm{PVH}$ are distinguished from other AVP-expressing populations by their capacity to express in abundance the type 2 glucocorticoid receptor (GR) (Uht et al., 1988), and evidence implicating CREB as a target for GR-mediated transcriptional repression (Stauber et al., 1992) raises the possibility that stress-induced GR activation limits the capacity of CREB to influence the otherwise CREBsensitive AVP transcriptional control apparatus. Although such a mechanism may play a role in restraining the AVP hnRNA response, our observations that CREB phosphorylation preceded a significant rise in plasma corticosterone, and the rapidity of the CRF transcriptional activation in this same neuronal population, are consistent with an involvement of additional factors, including induced IEG products, in the stress-induced rise in AVP hnRNA. Because the c-fos promoter itself contains a CRE that binds pCREB and is capable of powerfully stimulating Fos expression (Sassone-Corsi et al., 1988; Sheng et al., 1990), and evidence to support a functional dependence of Fos induction on CREB (Conradi et al., 1994) and of AVP mRNA responses on recent protein synthesis (Ding et al., 1994), in distinct in vivo settings, it is possible to envision a pCREB-dependent, IEG-based mechanism in the AVP transcriptional response to stress. In this regard, evidence for interaction of CREB with AP- 1 factors on a nonCRE of the AVP gene has been provided in vitro (Pardy et al., 1992). Relevant events may not be limited to ones involving DNA 
binding; demonstrated functional antagonism between AP-1 constituents and the GR via protein-protein interactions (Schule et al., 1990; Yang-Yen et al., 1990) may be particularly pertinent to the regulation of AVP expression by stress.

Brn-2 is a member of the POU-domain family of transcription factors that are important in the developmental specification of cellular phenotype and lineage (Wenger et al., 1993). It is relevant in this study in that stress-related neurosecretory neurons are among the few neuronal types that express Brn-2 into adulthood (He et al., 1989), the CRF promoter contains five distinct iterations of Brn-2-binding sites that are capable of conferring Brn-2 responsivity to a heterologous reporter in cotransfection assays (Li et al., 1993), and mice bearing targeted null Brn-2 mutations display a specific loss of neurosecretory CRF, AVP, and oxytocin neurons (Schoenemann et al., 1995). Despite the importance of Brn-2 in the genesis and/or survival of these cell types, we failed to detect ether-induced alterations in Brn-2 mRNA in the PVH. A comparable lack of responsiveness has been seen after other acute (hemorrhage, interleukin-1) and chronic (salt-loading) challenges (our unpublished observations). Although this may argue against a role for this factor in the acute regulation of neuroendocrine peptide expression, it is not known whether DNA binding and trans-activation by Brn-2 is dependent on post-translational modification (e.g., phosphorylation). If this proves to be the case, antisera specific to the active form of the protein would be required to evaluate the place of Brn-2 in the phenomena considered here.

\section{Transcription factors as markers of cellular activation}

In view of the substantial pool of AVP and/or CRF sequestered in terminals of parvocellular neurons (Whitnall et al., 1985, 1987), and the rapidity of their release in acute stress (e.g., Bruhn et al., 1984), the cellular responses described here seem to be viewed most aptly as serving to replenish stores of releasable peptide, thus preparing the animal for subsequent or prolonged challenges. A limitation on the use of IEGs to mark acutely "activated" neurons comes from the fact that induced protein synthesis occurs well after the termination of secretory responses, allowing counter-regulatory events to contribute to the IEG profile and complicate its interpretation. That pCREB and CRF hnRNA responses temporally approximate the stress-induced rise in plasma ACTH offers some promise in identifying an alternative set of reagents with which to surmount this limitation. The temporal resolution and potential mechanistic relevance afforded by pCREB in this system should not be taken as an indictment of the utility of IEGs as markers for functional mapping; c-fos, in particular, remains the most thoroughly and generally validated of such tools.

\section{REFERENCES}

Abercrombie M (1946) Estimation of nuclear population from microtome sections. Anat Rec 94:239-247.

Antoni FA (1986) Hypothalamic control of adrenocorticotropin secretion: advances since the discovery of 41-residue corticotropin-releasing factor. Endocrine Rev 7:351-378.

Antoni FA, Fink G, Sheward WJ (1990) Corticotropin-releasing peptides in rat hypophyseal portal blood after paraventricular lesions: a marked reduction in the concentration of corticotrophin-releasing factor-1, but no change in vasopressin. J Endocrinol 125:175-183.

Armstrong RC, Montminy MM (1993) Transsynaptic control of gene expression. Annu Rev Neurosci 16:17-29.

Borsook D, Konradi C, Falkowski O, Comb M, Hyman SE (1994) Molecular mechanisms of stress-induced proenkephalin gene regulation: CREB interacts with the proenkephalin gene in the mouse hypothala- mus and is phosphorylated in response to hyperosmolar stress. Mol Endocrinol 8:240-248.

Bruhn TO, Plotsky PM, Vale WW (1984) Effect of paraventricular lesions on corticotropin-releasing factor (CRF)-like immunoreactivity in stalk-median eminence: studies on the adrenocorticotropin response to ether stress and exogenous CRF. Endocrinology 114:57-62.

Buma P, Nieuwenhuys R (1987) Ultrastructural demonstration of oxytocin and vasopressin release sites in the neural lobe and median eminence of the rat by tannic acid and immunogold methods. Neurosci Lett 74:151-157.

Ceccatelli S, Villar MJ, Goldstein M, Hökfelt T (1989) Expression of c-fos immunoreactivity in transmitter-characterized neurons after stress. Proc Natl Acad Sci USA 86:9569-9573.

Chan RKW, Brown ER, Ericsson A, Kovács KJ, Sawchenko PE (1993) A comparison of two immediate-early genes, c-fos and $N G F I-B$, as markers for functional activation in stress-related neuroendocrine circuitry, $\mathrm{J}$ Neurosci 13:5126-5138.

DeGoeij DC, Kvetnansky R, Whitnall MH, Jezova D, Berkenbosch F, Tilders FJ (1991) Repeated stress-induced activation of corticotropinreleasing factor neurons enhances vasopressin stores and colocalization with corticotropin-releasing factor in the median eminence of rats. Neuroendocrinology 53:150-159.

Ding JM, Carver WC, Terracio L, Buggy J (1994) Proto-oncogene $c$-fos and the regulation of vasopressin gene expression during dehydration. Mol Brain Res 21:247-255.

Dorin RI, Zlock DW, Kilpatrick K (1993) Transcriptional regulation of human corticotropin relcasing factor genc expression by cyclic $3^{\prime}, 5^{\prime}$ monophosphate: differential effects at proximal and distal promoter elements. Mol Cell Endocrinol 96:99-111.

Ericsson A, Kovács KJ, Sawchenko PE (1994) A functional anatomical analysis of central pathways subserving the effects of interleukin- 1 on stress-related neuroendocrine neurons. J Neurosci 14:897-913.

Ginty DD, Bonni A, Greenberg ME (1994) Nerve growth factor activates a Ras-dependent protein kinase that stimulates c-fos transcription via phosphorylation of CREB. Cell 77:713-725.

Ginty DD, Kornhauser JM, Thompson MA, Bading H, Mayo KE, Takahashi JS, Greenberg ME (1993) Regulation of CREB phosphorylation in the suprachiasmatic nucleus by light and a circadian clock. Science 260:238-241.

Gonzalez GA, Montminy MR (1989) Cyclic AMP stimulates somatostatin gene transcription by phosphorylation of CREB at serine 133. Cell $59: 675-680$.

Guardiola-Diaz HM, Boswell C, Seasholtz AF (1994) The cAMP-responsive element in the corticotropin-releasing hormone gene mediates transcriptional regulation by depolarization. J Biol Chem 269:14784-14791.

Hagiwara M, Brindle P, Harootunian A, Armstrong R, Rivier J, Vale W, Tsien R, Montminy MR (1993) Coupling of hormonal stimulation and transcription via the cyclic AMP-responsive factor CREB is rate limited by nuclear entry of protein kinase A. Mol Cell Biol 13:4852-4859.

Harbuz MS, Lightman SL (1992) Stress and the hypothalamo-pituitaryadrenal axis: acute, chronic and immunological activation. J Endocrinol 134:327-339.

He X, Treacy M, Simmons D, Ingraham H, Swanson LW, Rosenfeld M (1989) Expression of a large family of POU-domain regulatory genes in mammalian development. Nature 340:35-42.

Herman JP (1995) In situ hybridization analysis of vasopressin gene transcription in the paraventricular and supraoptic nuclei of the rat regulation by stress and glucocorticoids. J Comp Neurol, in press.

Herman JP, Schafer MK-H, Sladek CD, Day R, Young EA, Akil H (1989) Chronic electroconvulsive shock treatment elicits up-regulation of CRF and AVP in select populations of neuroendocrine cells. Brain Res 501:235-246.

Herman JP, Schafer M, Thompson RC, Watson SJ (1992) Rapid regulation of corticotropin-releasing hormone gene transcription in vivo. Mol Endocrinol 6:1061-1069.

Herman JP, Schafer MK-H, Watson SJ, Sherman TG (1991) In situ hybridization analysis of arginine vasopressin gene transcription using intron-specific probes. Mol Endocrinol 5:1447-1456.

Hoffman GE, Verbalis JG, Smith MS (1993) c-Fos and related immediate early gene products as markers of activity in neuroendocrine systems. Front Neuroendocrinol 14:173-213.

Holmes MC, Antoni FA, Aguilera G, Catt KJ (1986) Magnocellular axons in passage through the median eminence release vasopressin. Nature 319:326-329. 
Imaki T, Shibasaki T, Hotta M, Demura D (1992) Early induction of c-fos precedes increased expression of corticotropin-releasing factor messenger ribonucleic acid in the paraventricular nucleus after immobilization stress. Endocrinology 131:240-246.

Kiss JZ, Mezey E, Skirboll L (1984) Corticotropin-releasing factor-immunoreactive neurons of the paraventricular nucleus become vasopressin positive after adrenalectomy. Proc Natl Acad Sci USA 81:1854-1858.

Konradi C, Cole RL, Heckers S, Hyman SE (1994) Amphetamine regulates gene expression in rat striatum via transcription factor CREB. J Neurosci 14:5623-5634.

Kovács KJ, Makara GB (1988) Corticosterone and dexamethasone act at different brain sites to inhibit adrenalectomy-induced adrenocorticotropin hypersecretion. Brain Res 474:205-210.

Kovács KJ, Makara GB (1990) Partial deafferentation of the hypothalamic paraventricular nucleus: effect on the stress- or adrenalectomyinduced ACTH secretion. Neuroendocrinol Lett 12:383-389.

Kovács KJ, Sawchenko PE (1994) Stress-induced transcriptional activation of the corticotropin-releasing factor gene precedes immediate-early genes responses in the paraventricular nucleus. Soc Neurosci Abstr $20: 935$

Lalli E, Sassone-Corsi P (1994) Signal transduction and gene regulation: the nuclear response to cAMP. J Biol Chem 269:17359-17362.

Li P, He X, Gerrero MR, Mok M, Aggarwal A, Rosenfeld MG (1993) Spacing and orientation of bipartite DNA-binding motifs as potential functional determinants from POU domain factors. Genes Dev $7: 2483-2496$

Lightman SL, Young III WS (1988) Corticotropin-releasing factor, vasopressin and proopiomelanocortin mRNA responses to stress and opiates in the rat. J Physiol (Lond) 403:511-523.

Majzoub JL, Emmanuel R, Adler G, Martinez C, Robinson B, Wittert G (1993) Second messenger regulation of mRNA for corticotropin-releasing factor. The Netherlands: Ciba Foundation Symposium 172, pp $30-43$.

Morgan JI, Curran T (1991) Stimulus-transcription coupling in the nervous system: involvement of the inducible proto-oncogenes fos and jun. Annu Rev Neurosci 14:421-451.

Pardy K, Adan RAH, Carter DA, Seah V, Burbach JPH, Murphy D (1992) The identification of a cis-acting element involved in cyclic $3^{\prime}, 5^{\prime}$-adenosine monophosphate regulation of bovine vasopressin gene expression. J Biol Chem 267:21746-21752.

Plotsky PM (1991) Pathways to the secretion of adrenocorticotropin: a view from the portal. J Neuroendocrinol 3:1-9.

Priou A, Oliver C, Grino M (1993) In situ hybridization of argininc vasopressin (AVP) heteronuclear ribonucleic acid reveals increased AVP gene transcription in the rat hypothalamic paraventricular nucleus in response to emotional stress. Acta Endocrinol 128:466-472

Rivier C, Rivier J, Vale W (1982) Inhibition of adrenocorticotropic hormone secretion in rat by immunoneutralization of corticotropin-releasing factor (CRF). Science 218:377-379.

Rivier C, Vale W (1983) Interaction of corticotropin-releasing factor and arginine vasopressin on adrenocorticotropin secretion in vivo. Endocrinology 113:939-942.

Rivier C, Vale W, Guillemin R (1973) An in vivo corticotropin-releasing factor (CRF) assay based on plasma levels of radioimmunoassayable ACTH. Proc Soc Exp Biol Med 142:842-845.

Sassone-Corsi P, Visvader J, Ferland L, Mellon PL, Verma IM (1988) Induction of proto-oncogene fos transcription through the adenylatecyclase pathway: characterization of a cAMP-responsive element. Genes Dev 2:1529-1538

Sawchenko PE, Arias CA, Mortrud M (1993a) Evidence for synaptic mediation of chronic stress effects on corticotropin-releasing factor and vasopressin mRNAs in hypophysiotropic neurons. J Neuroendocrinol 5:341-348.

Sawchenko PE, Cunningham Jr ET, Mortrud MT, Pfeiffer SW, Gerfen CR (1990) Phaseolus vulgaris-leucoagglutinin anterograde axonal transport technique. In: Methods in neurosciences, Vol 3 (Conn PM, ed), pp 247-260. New York: Academic.

Sawchenko PE, Imaki T, Potter E, Kovács KJ, Vale W (1993b) The functional neuroanatomy of corticotropin-releasing factor. In: Corticotropin-releasing factor, Ciba Foundation Symposium 172 (Chadwick DJ, Marsh J, Ackrill K, eds), pp 5-29. Chichester: Wiley.
Sawchenko PE, Swanson LW (1982) The organization of noradrenergic pathways from the brainstem to the paraventricular and supraoptic nuclei in the rat. J Comp Neurol 205:260-272.

Sawchenko PE, Swanson LW, Vale WW (1984) Co-expression of corticotropin-releasing factor and vasopressin immunoreactivity in parvocellular neurosecretory neurons of the adrenalectomized rat. Proc Natl Acad Sci USA 81:1883-18876.

Schoenemann MD, Ryan AK, McEvilly RJ, O'Connell SM, Arias CA, Kalla K, Li P, Sawchenko PE, Rosenfeld MG (1995) Development and survival of the endocrine hypothalamus and posterior pituitary gland requires the neuronal POU domain factor Brn-2. Genes Dev, in press.

Schule R, Rangarajan P, Kliewer S, Ransone LJ, Bolado J, Yang N, Verma IM, Evans RM (1990) Functional antagonism between oncoprotein $c-j u n$ and the glucocorticoid receptor, Cell 62:1217-1226.

Seasholtz AF, Thompson RC, Douglass JO (1988) Identification of a cyclic adenosine monophosphate-responsive element in the rat corticotropin-releasing hormone gene. Mol Endocrinol 2:1311-1319.

Sheng M, McFadden G, Greenberg ME (1990) Membrane depolarization and calcium induce $c$-fos via phosphorylation of transcription factor CREB. Neuron 4:571-582.

Simmons DM, Arriza JL, Swanson LW (1989) A complete protocol for in situ hybridization of messenger RNAs in brain and other tissues with radiolabeled single-stranded RNA probes. J Histotechnol 12:169-181.

Stauber C, Altschmeid J, Akerblom IE, Marron JL, Mellon PL (1990) Mutual cross-interference between glucocorticoid receptor and CREB inhibits transactivation in placental cells. New Biol 4:527-540.

Swanson LW, Kuypers HGJM (1980) The paraventricular nucleus of the hypothalamus: cytoarchitectonic subdivisions and the organization of projections to the pituitary, dorsal vagal complex and spinal cord as demonstrated by retrograde fluorescence double labeling methods. J Comp Neurol 194:555-570.

Swanson LW, Simmons DM (1989) Differential steroid hormone and neural influences on peptide mRNA levels in CRH cells of the paraventricular nucleus: a hybridization histochemical study in the rat. $J$ Comp Neurol 285:413-435.

Uht RM, McKelvy JF, Harrison RW, Bohn M (1988) Demonstration of glucorticoid receptor-like immunoreactivity in glucocorticoid-sensitive vasopressin and corticotropin-releasing factor neurons in the hypothalamic paraventricular nucleus. J Neurosci Res 19:405-411.

Verbeeck MAE, Adan RAH, Burbach JPH (1990) Vasopressin gene expression is stimulated by cyclic AMP in homologous and heterologous expression systems. FEBS Lett 272:89-93.

Vallejo M (1994) Transcriptional control of gene expression by cAMPresponse element binding proteins. J Neuroendocrinol 6:587-596.

Watts AG (1991) Ether anesthesia differentially affects the content of prepro-corticotropin-releasing hormone, prepro-neurotensin/neuromedin $\mathrm{N}$ and prepro-enkephalin mRNAs in the hypothalamic paraventricular nucleus of the rat. Brain Res 544:353-357.

Watts AG, Swanson LW (1989) The combination of in situ hybridization with immunohistochemistry and retrograde tract-tracing. In: Methods in neurosciences (Conn PM, ed), pp 127-136. New York: Academic.

Wenger M, Drolet DW, Rosenfeld MG (1993) POU-domain proteins: structure and function of developmental regulators. Curr Opin Cell Biol $5: 488-498$

Whitnall MH (1993) Regulation of the hypothalamic corticotropin-releasing hormone neurosecretory system. Prog Neurobiol 40:573-629.

Whitnall MH, Mezey E, Gainer H (1985) Co-localization of corticotropin-releasing factor and vasopressin in median eminence neurosecretory vesicles. Nature 317:248-250.

Whitnall MH, Smythe D, Gainer H (1987) Vasopressin coexists in half the corticolropin-releasing factor axons present in the external zone of the median eminence in normal rats. Neuroendocrinology 45:420-424.

Yang-Yen HF, Chambard JC, Sun YL, Smeal T, Schmidt TJ, Drouin J, Karin $M$ (1990) Transcriptional interference between $c$-jun and the glucocorticoid receptor: mutual inhibition of DNA binding due to direct protein-protein interaction. Cell 62:1205-1215.

Young III WS, Mezey E, Siegel RE (1986) Vasopressin and oxytocin mRNAs in adrenalectomized and Brattleboro rats: analysis by quantilative in situ hybridization histochemistry. Mol Brain Res 1:231-241. 